\title{
Nutritional and Biological evaluation of using Spirulina algae as anew source of protein Salha Salem Algohary ${ }^{1}$, Zainab Abdul-Wahhab Salem ${ }^{1}$ and *Amira M. El-Moslemany ${ }^{1}$ \\ 1. Nutrition and Food Science Department, Faculty of Home Economics, Al-Azhar University, Egypt. \\ *Corresponding author: Amira M. El-Moslemany \\ Email: amiraelmoslemany@azhar.edu.eg
}

\section{ABSTRACT}

Pirulina platensis (SP) alga has been a common dietary substance around the N world from ancient times. This study was aimed to using Spirulina as a novel protein source, especially in growth phase. Thirty six male albino rats aged six weeks were divided into six groups according to the protein source as following: The casein groups (C1, C2, and C3) contain (100, 200, and $300 \mathrm{~g}$ casein $/ \mathrm{kg}$ diet) as (10\%, $20 \% \& 30 \%$ casein), respectively. On the corresponding side, the spirulina clusters (SP1, SP2, and SP3) contained $(157,315$ and $472 \mathrm{gm}$ algal protein/kg food) respectively. It lasted 28 days. SP has high total antioxidant activity (39.2 \%). SP groups recorded significant increases in feed intake, body weight gain, feed efficiency ratio and protein efficiency ratio compared with casein groups. While casein recorded significant increases in apparent digestibility, Co-efficient compared to groups of SP algae. Eating Spirulina has significantly preserved liver and kidney function. As for complete blood picture, the groups of SP3 recorded highest percentage in $\mathrm{Hb}$ and RBCs compared with C3 group, other than WBCs, which was lower in SP3. Significant increase in the antioxidant enzymes in liver tissues were observed in SP groups, while Malondialdehyde recorded a significant reduction in the same groups. SP treatment increased GH levels in all groups. On the other side, the results of alpha tumor necrosis factors recorded a significant decrease in groups of SP compared with the groups of casein. In conclusion, Spirulina can be used as a new protein replacement.

Key words: Spirulina algae - protein substitutes - Hematological parameters antioxidant enzymes. 


\section{Nutritional and Biological evaluation of using Spirulina algae as anew source of protein}

Salha Salem Algohary, Zainab Abdul-Wahhab Salem and Amira M. El-Moslemany

\section{INTRODUCTION}

Protein

characterized by low protein intake, reduces plasma amino acid concentrations and weakens the immune system (Fechner et al., 2001). According to the World Health Organization (WHO), approximately $30 \%$ of the world's population is malnourished and 40,000 children die every day due to malnutrition and related diseases (WHO, 2011). Protein energy malnutrition(PEM) and micronutrient deficiency leading to early growth traced to poor maternal nutritional and health care before and during pregnancy, resulting in intrauterine growth retardation and children born with low birth weight, while significant progress has been achieved over the past 30 years in reducing the proportion of malnourished children in developing countries (Udayasree et al., 2013).

Technicians of the WHO have discussed the discovery and use of new protein sources as well as rules to use them in the food. In that sense, microorganisms have been studied as possible sources of protein. Use of cyanobacteria as a source of protein has certain advantages in relation to other microorganisms due to their rapid growth in addition to the quantity and quality of protein (Molina $\boldsymbol{e t}$ al., 2002). One of such food, which constitutes the most remarkable concentration of nutrients, is "Spirulina" which combat malnutrition undernourishment, and protein deficiencies. Spirulina is a bluegreen microalgae has a spiral cellular structure, and has an extraordinary capacity to survive under conditions that are much too harsh for other algae two species of Spirulina that are most commonly used in nutritional supplements are Spirulina platensis(SP) and Spirulina maxima (Khan et al., 2005).

Spirulina contains, approximately, $65 \%$ to $71 \%$ protein by dry weight and is claimed to be non-toxic nutritious food with exceptional properties. It contains $47 \%$ of essential amino acids, methionine, which is usually absent in other algae, and cyanobacteria, $15-25 \%$ carbohydrates, $8-13 \%$ minerals, 3-7\% fat, $8-10 \%$ fiber. It also contains chlorophyll, phycocyanin, carotenoids, minerals, vitamins, essential fatty acids, and other bioactive components (Iyeret al., 2008). Spirulina is increasingly incorporated into bread and other bakery products such as cassava cake (Navacchi et al., 2012), biscuits (Sharma and Dunkwal, 2012) and sweet bread (Minh, 2014).

Siva Kiran et al., (2015) mentioned that Spirulina is a 
simple extract of blue-green algae, which is now used worldwide as a food product and as a dietary supplement. It contains, essential amino acids, lipids, vitamins, minerals and anti-oxidants and can be considered as a wholesome food supplement.

Sinha et al., (2019) evaluated the effects of dietary Spirulina supplementation of protein malnourished mothers during pregnancy and lactation on their offspring's reflex, neurobehavioral and cognitive development. The study has shown improved reproductive performance of Spirulina supplemented protein malnouri-shed dams, accelerated acquisition of neurological reflexes, better physical appearance, enhanced neuromuscular strength, improved spatial learning and memory and partly normalized protein malnutrition induced hyper-activity, anxiolytic and a hedonic behavior in offspring.

Recent studies have associated consumption of Spirulina supplements with signifycant immunomodulatory, proinflammatory, antioxidant, anticancer, and antiviral activities, both in animal models and in human subjects. Hypolipidemic, hypoglycemic, and hypotensive effects are also being uncovered, and there is clear evidence of further beneficial health effects on its consumption; however, research into its hepatic effects is still relatively limited (Reboleira et al., 2019). Cho et al., (2020) observed that Spirulina enhanced bone growth and bone strength by stimulating parathyroid hormone and growth hormone activities, as well its increased antioxidant activity. Their results have indicated that Spirulina provides a suitable dietary supplement and alternative protein source with antioxidant benefits for growth improvement in early developmental stages. Therefor we hypothesized that spirulina, a plantorigin protein, could be a functional substitution for animal protein, in this case, casein protein. Therefore, this work aimed to evaluate the effects of using Spirulina as a protein substitute and its antioxidant effect on the growth-related hormone levels and the biochemical and hematological aspects of the blood in growing male rats.

\section{MATERIALS and METHODS}

Materials:

- Spirulina platensis (SP) algae powder: It was be obtained from Nour Alhuda for Training and Management of Agriculture Projects, Cairo, Egypt. 
- Animals: Thirty-six young male albino rats (Sprague Dawley strain) weighed $(80 \pm 10 \mathrm{~g})$ were be obtained from Vaccine and Immunity Organization, Helwan Farm, Cairo, Egypt.

- Kits were be purchased from Egyptian American Company for Laboratory Service.

- Corn oil and starch were be purchased from the local market. Casein, cellulose, vitamins, minerals, Sucrose and methionine were obtained from the Cairo Company for Chemical Trading, Cairo, Egypt.

- Diet: Composition of experimental diets ( $\mathrm{g} / \mathrm{kg}$ diet) according to NCR, (1995) and some modification.

\section{Methods:}

\section{Chemical analysis of Spirulina algae:}

Carbohydrates, Protein, fat, moisture, fiber and ash of algae were determined according to the methods described by A.O.A.C, (2010). Amino acid analysis is a technique based on ion exchange liquid chromategraphy, used in a wide range of application areas to provide qualitative and quantitative compositional analysis. In the biochrom systems, this basic principle has been refined to produce fully automatic, high speed, sensitive analyses. This is sometimes referred to as classical amino acid analysis according to the method described by Pearson, (1981). Antioxidant activity was calculated according to the methods described by Moukette et al., (2015).

\section{Experimental design:}

After adaptation period (one week), in well- aerated cages under hygienic condition and fed on basal diet and water supply $a d$ libitum. The rats divided into six groups (6 rats each) as following: Group (1) fed on basal diet (casein $100 \mathrm{~g} / \mathrm{kg}$ diet) .Group (2) fed on basal diet (Spirulina $157 \mathrm{~g} / \mathrm{kg}$ diet as a casein replacement).Group (3) fed on basal diet (casein200g/ kg diet) .Group (4) fed on basal diet (Spirulina 315g/ kg diet as a casein replacement). Group (5) fed on basal diet (casein $300 \mathrm{~g} / \mathrm{kg}$ diet). Group (6) fed on basal diet (Spirulina 472g/ kg diet as a casein replacement).Total faeces for each rat in each group was collected at the end of the seven days $(8 \mathrm{am})$. Faeces were weighed, mixed thoroughly and sun-dried, reweighed, ground to pass through one $\mathrm{mm}$ screen. The ground sample for each rat was stored in paper bags for dry matter and protein analysis. At the end of experiment (28) days, The urine dipstick test was performed along with 24-hour urine samples, the animals were be deprived of food 
and water overnight before being sacrificed. Blood samples were be collected in dry centrifuge tubs from hepatic portal veins. Serum samples were be separated by centrifugation at $4000 \mathrm{rpm}$ for 10 minutes and kept in Eppendorf tube at -20 until analysis. The liver was be removed, washed with isotonic saline, dried by filter paper and weighted. Liver sample was be kept at $-20^{\circ} \mathrm{C}$ for preparation of tissue homogenate for determination of antioxidant parameters. The homogenate was be centrifuged at $10,000 \mathrm{rpm}$ for $20 \mathrm{~min}$. The supernatant was be used for the assay of some laboratory analyses.

\section{Nutritional and Biological parameters}

During the experimental period, the diet consumed was recorded twice weekly, and body weight recorded every week. The body weight gain (BWG) and feed efficiency ratio (FER) were evaluation according to Champman et al., (1959). Protein efficiency ratio (PER), calculated as the ratio of weight gain (g) and total protein consumed (Sgarbieri, 1996).

Apparent digestibility Co-efficient $=$ protein intake - fecal protein / protein intake

\section{Hematological investigations}

Complete blood count was performed on blood samples with anticoagulant using hematological analyzer (Exigo Eos Vet, Sweden). The erythrogram consisted of red blood cell count (RBCs), hematocrit (HCT), hemoglobin $(\mathrm{Hb})$ concentration and red cell indices, mean corpuscular volume (MCV), mean corpuscular hemoglobin (MCH), mean corpuscular hemoglobin concentration (MCHC) and red blood cell distribution width absolute (RDWa), leukogram (includes white blood cell count (WBCs), lymphocytes (\%), monocytes (\%)and platelet count (PLT) according to (Jain, 1986).

\section{-Biochemical analysis of serum and urine}

Serum samples were used for the determination of the concentrations of tumor necrosis factor- $\alpha$ (TNF- $\alpha)$ and growth hormone (GH) measured using automated biochemistry analyzer (SPIN120-Spinreact-benchtop 8 wavelengths: 340 and $670 \mathrm{~nm}$ ) according to Gao et al., (2015). Aspartate aminotransferase (AST) and alanine aminotransferase (ALT) were determined according to Bergmeyer et al., (1986). Alkaline phosphatase (ALP) activity was estimated according to Kind and King, (1954). Albumin (Drupt, 1974) and total protein were determined according to (Sonnenwirth and 
Jaret, 1980). Urea nitrogen, creatinine and uric acid were evaluated in serum according to Patton et al.,(1977); Faulkner and King, (1976) and Fossati $e t$ al., (1980) respectively .Creatinine clearance $(\mathrm{Cr} \mathrm{Cl})$ was calculated by the formula: Clcr=urine creatinine $(\mathrm{mg} / \mathrm{dL}) \mathrm{x}$ urine flow $(\mathrm{mL} / \mathrm{min}) \quad /$ Serum creatinine $(\mathrm{mg} / \mathrm{dL})$.

\section{Assessment of Oxidant /} Antioxidant Activity in liver tissue

After then liver removed, homogenized and centrifuged at $10,000 \mathrm{rpm}$ at $4^{\circ} \mathrm{C}$ for $20 \mathrm{~min}$. The supernatant was used for estimation of different antioxidant level by calorimetric method with a spectrophotometer Elisa (micro plate reader Ryto2100 C) at (520 and $535 \mathrm{~nm}$ )Manoldehyde (MDA) by thiobarbuturic acid-reactive substances (TBARS) methods (Uchiyama and Mihara 1978), Superoxide dismutase (SOD) by method developed by Misra and Fridovich, (1972) and Catalase (CAT) by colorimetric assay (Sinha,1972). Glutathione peroxidase (GPx) was carried out according to Pablos et al., (1998).

\section{Statistical analysis}

Results are expressed as mean \pm standard deviation (SD). Differences between means indifferent groups were tested for significance using a one-way analysis of variance (ANOVA) followed by Duncan's test and $\mathrm{P}$ value of 0.05 or less was considered significant according to (Snedecor, 1969) using SPSS (vertion20).

\section{RESULTS \& DISCUSSION}

Chemical composition of SP (Protein, carbohydrates, ash, lipids, moisture, and crude fiber) per $100 \mathrm{~g}$ on the dry weight basis was presented in Table (1). SP contains Protein, carbohydrate and ash $(54 \pm 1.43,12.50 \pm 0.40$ and $11.05 \pm 0.21$ (g/ 100g DW), respectively. Also SP has high total antioxidant activity (39.2 $\%)$.These data agree with ElMoataaz et al.,( 2019) and Cho et al., (2020) who found that SP contains a high amount of protein .The protein content was of high quality as it comprised of essential amino acids and non-essential amino acids.

$$
\text { Data in Table }
$$

confirmation the effect of using SP algae as a casein replacement on feed intake, BWG, FER, and apparent digestibility Co- efficient in young male rats. It could be noticed that the groups of SP $(1,2$ and3) recorded significant increases in feed intake, BWG, FER and PER compared with casein groups. However, on the other side the groups of casein 
recorded significant increases in apparent digestibility Co-efficient compared to groups of SP algae. This corresponds to Gargouri et al., (2020) who found that treatment of SP improved food, water consumption and body weight gain in rats treated with lead $(\mathrm{Pb})$. Also in another study was performed by El-Beltagi $\boldsymbol{e t}$ al., (2020) who evaluated hepatoprotective and antioxidant activities of (SP) and pomegranate juice $(\mathrm{PJ})$ in rats against hepatotoxicity induced by carbon tetrachloride (CCl4). They noticed that (SP) and (PJ) significantly increased in weight gain relative to normal control and $\mathrm{CCl} 4$ treatment groups, It is presumed that treatments used with PJ, SP and their combination may boost appetite and increase weight gain. The improvement in body weight gain also noticed in diabetic Wistar rats treated with SP (Aissaouia et al., 2017). Dernikabsi et al., (2010) studied the effect of dietary supplementation of different rates of SP on growth and feed conversion in guppy, the groups treated with SP recorded significant increases in feed intake and body weight gain specially the groups of $30 \& 40 \%$ of spirulina. Moreira et al., (2013) evaluated the effects of SP as a protein source in the nutritional recovery of rats subjected to protein malnutrition. The SP treatment showed the highest values of (FER) and Quotient of Protein Efficiency Ratio (QPE) $(p \leq 0.05)$. These results demonstrated that the nutritional recovery of animals was enabled by different concentrations of SP. These results disagree with Heidarpour et al., (2011) who investigated the effects of different amounts of SP on the performance and digestibility of dry matter (DM) of Holstein calves. Results showed that treatment effect was not significant on the final weight, daily gain, daily feed intake, feed efficiency and digestibility coefficient $\quad(\mathrm{P}>0.05), \quad$ while increase in the SP level up to 25 $\mathrm{g}$, decreased digestibility of DM. Digestibility of DM in the control diet was higher than those of SP diets. It was interesting that increased in the SP level led to decrease in digestibility of all mentioned nutrient materials.

Data in Table 3 show the effect of SP algae as a casein replacement on serum AST, ALT and ALP. The mean values of AST, ALT and ALP in groups of SP $(1 \& 2)$ are similar to groups of casein $(1 \& 2)$.But the mean values of AST, ALT and ALP in groups of SP1 and casein 1 recorded a significant decrease compared to casein 2. SP 2 maintains the liver 
biomarker in this experiment. These results are similarly for a study by Moreira et al., (2013) who evaluated the effects of SP (Arthrospira) as a protein source in the nutritional recovery of rats subjected to protein malnutrition. They found that serum levels of the activities of AST and ALT revealed no values statistically different from the control group. The results matched with Cho $\boldsymbol{e t}$ al., (2020) who evaluated the effects of SP on the bone metabolism and antioxidant profiles of three-week-old growing male rats. They found that no significant difference between the spirulina substitution diets and the control diet at 7 weeks in liver functions. SP protects against oxidative stress either by free radical scavenging or by enhancing SOD and CAT activities accordance to BinJumah et al., (2021) who evaluated the ameliorative effect of SP against acrylamide (AA) toxicity in rats. They found that SP supplementation at a dose of $500 \mathrm{mg} / \mathrm{kg}$ in the AA-intoxicated group markedly reduce $(\mathrm{P} \leq 0.05)$ the serum levels of ALT, AST, and ALP. El-Beltagi et al., (2020) evaluated hepatoprotective and antioxidant activities of SP and pomegranate juice $(\mathrm{PJ})$ in rats against hepatotoxicity induced by carbon tetrachloride (CCl4).They found that SP extract and its combination (PJSP) also showed a substantial reduction compared to the liver injury management group of rats. The liver markers were be improved after receiving gradient doses of SP and pomegranate juice. Xiang et al., (2018) studied the protective effect and mechanism of selenium-enriched SP on chronic alcohol-induced liver injury. Their results indicated that the protective mechanism of selenium-enriched SP on chronic alcoholic liver injury is associated with the activity enhancement of antioxidant enzymes and immunity, the inhibition of DNA damage and apoptosis, accompanied with autophagy and pyro ptosis. As well as Aissaouia et al., (2017) investigated the antioxidant effects of SP in diabetic Wistar rats. They found significant decreased in the groups treated by $\mathrm{SP}$ in the oxidative stress parameters AST, ALT ( $\mathrm{p}<$ 0.001 ) in comparison to those of the controls after 70 days. SP dietary supplementation reduced the serum hepatic biomarkers, had a good protection and maintained the structural integrity of hepatocellular membrane (AbdelDaim, 2014) (Abdelkhalek et al., 2014). This may be due to the antioxidant activity of Spirulina phycobiliproteins (phycocyanins and allophycocyanins) or phenolic 
compounds (Nuhu, 2013; AbdelDaim et al., 2016). On the other side SP 3 and casein 3 recorded significant increases in these parameters compared to casein2(control group). This is in agreement with Díaz-Rúaet al., Data in Table 4 demonstration the effect of SP alga as a casein replacement on serum total protein, albumin and globulin. Total protein recorded non-significant differences among groups of casein and SP groups (1\&2). SP may inhibited the growth of harmful bacteria in intestine, as presented by Bhowmik et al., (2009) who found the lower value of serum globulin of rabbits fed at 5\% SP. They mentioned that might be attributed to the inhibitory effect of SP against harmful intestinal microflora. Because harmful enteric bacteria secretes inflammatory agents and lead to increase in globulin synthesis of liver or of other tissues such as lymphatic tissue or plasma cells. Ramez et al., (2021) investigated the therapeutic effects of SP and Matcha green tea (MGT) in Schistosomamansoni-infected mice combined with tracing their possible antioxidant and antiinflammatory impacts and their protective potency. Treatment with the combination of SP and
(2017) who found that using high protein in diet resulting in a high acid load increased TG deposition and increased signs of health risk (increased inflammation, alterations in the acid-base equilibrium and oxidative stress) in rats .

MGT (SP- MGT-infected group) significantly restored serum total protein and globulin to concentrations similar to those of the uninfected controls $(\mathrm{P}<0.05)$. Khanna et al., (2016) studied the effect of Emblicaofficianalis and Spirulina platensis was studied in New Zealand White rabbits. They found there were no significant changes in the serum biochemical indices, only the serum globulin value was significantly $(\mathrm{P}<0.05)$ lower and albumin value was found significantly higher in the groups fed spirulina supplemented diets as compared to groups fed with non-supplemented diets. On the other side casein 3recorded a significant increase in these parameters compared to casein2 (normal control). These results agree with Nour El-Deen $\boldsymbol{e t}$ al., (2018) who found that a high protein intake in diabetic obese albino rats and normal rats led to changes in serum total protein and urine levels of markers of renal function, which indicated abnormalities in the functions of the kidney. 
Data in Table 5 show the effect of SP algae as casein replacement on urea, uric acid, creatinine and creatinine clearance of rats. The mean values of urea, creatinine and creatinine clearance in the groups of SP $(1 \& 2)$ are similar to groups of casein $(1 \& 2)$. Nevertheless, the mean value of uric acid of SP and casein groups 1 recorded a significant increase compared to casein 2. On the other hand, casein 3 and SP 3 recorded a significant increase in these parameters compered to casein 2. SP 3 recorded a significant decrease in these parameters compared to casein 3.Moreira et al., (2013) evaluated the effects of SP as a protein source in the nutritional recovery of rats subjected to protein malnutrition. They noticed that all the treatments with SP had creatinine levels statistically similar to the control; however, when comparing the treatments with SP with each other, S2 showed significantly lower values ( $p \leq 0.05$ ). High concentration of casein affect kidney functions. Aparicio et al., (2013) found that high-protein diet promoted a worse renal profile, especially on urinary and morphological markers, which could increase the risk for developing renal diseases in the long time. Protein ingestion increases renal acid excretion, and acid loads, in turn, may be buffered in part by bone, which releases calcium to be excreted by the kidney. This protein-induced hypercalciuria could lead to the formation of calcium kidney stones (Goldfarb, 1988). Gargouri et al., (2020) noticed that a significant reduction in creatinine clearance, an indicator of glomerular dysfunction, was observed in the $\mathrm{Pb}$-treated female rats. Co administration of SP caused a marked improvement of urea, uric acid and creatinine. BinJumah et al., (2021) agreed with the present results, when they evaluated the ameliorative effect of SP against AA toxicity in rats. They found the levels of urea, creatinine were markedly reduced. This improvement was due to the enhanced restoration of the tubular malfunction under the influence of a biliprotein pigment called phycocyanin drug, which is present in SP and had a diuretic activity. Another thing clarify the increase of diuresis is the presence of flavonoids and potassium in SP algae (Abdel-Daim, 2014).

Data in Table 6 expression the effect of using SP algae as a casein replacement on $\mathrm{Hb}, \mathrm{RBC}_{\mathrm{s}}$ and WBCs. The results illustration that there were a significant increase in groups of SP compared with the groups of casein. The groups of SP3 and C3 
recorded highest percentage in $\mathrm{Hb}$ and RBCs compared with $\mathrm{C} 2$ group, other than WBCs, which was lower in SP3. The improvement in theses parameters for SP group may be due to contain a high percentage of protein. In addition, SP contains high iron, about $28.5 \mathrm{mg} / 100 \mathrm{gm}$, of which 58 times more than in spinach, and 18 times higher than that found in meat. Consumption of $100 \mathrm{gm}$ of SP can fulfill $158 \%$ of iron needed in a day (Marlina, 2019). These results agree with Gargouri et al., (2020) who investigated the effect of SP against the hemato-biochemical alterations and nephrotoxicity induced by lead $(\mathrm{Pb})$. They noticed that treated with SP occurs the changes in blood indices shown in $\mathrm{Pb}$-treated group were reverted to near normal levels upon co-treatment with SP. Mohammadizarm et al.,(2020) studied the effect of SP meal as a feed additive on growth and physiological response of Oscar fish. They found that $\mathrm{Hb}$ was improved markedly in different SP treatments, and develop the cellular immune system and red blood cells. Marlina, (2019) stated that SP might ameliorate anemia among women in the second trimester of pregnancy. Also, Rajachar et al., (2016) emphasized in their randomized study of 1000 children that consuming spirulina in doses (1 and 2 grams) led to an increase in hemoglobin level as well as a significant improvement in their mental abilities and their academic level.

The table 7 illustrates the effect of using SP algae as a casein replacement on hematocrit, monocytes, lymphocytes and P.Count. The results of hematocrit, lymphocytes, and monocytes recorded significant increases in groups of SP compared with normal control. In the other side, P.Count recorded a significant decrease in groups of SP compared with the groups of casein. These results agree with Gargouri et al., (2020) who investigated the effect of SP against the hemato-biochemical alterations and nephrotoxicity induced by lead $(\mathrm{Pb})$. They noticed that treated with SP occurs the changes in blood indices shown in $\mathrm{Pb}$-treated group were reverted to near normal levels upon cotreatment with SP. The present results were in line with Moreira et al., (2013) who evaluated the effects of SP as a protein source in the nutritional recovery of rats subjected to protein malnutrition. Where they found that hematocrit recorded a significant increase ingroup 10, $20 \%$ of SP compared with control group. However, they 
recorded significant decrease in group $30 \%$ of SP compared with control group. Other than what was found in this research, SP3 raised the hematocrit level compared with casein group.

As shown in Table 8, SP algae groups recorded significant increases in $\mathrm{MCH}, \mathrm{MCV}$ and MCHC compared with casein 2. In addition, these results agree with Mohammadizarm et al.,(2020) who studied the effect of spirulina meal SP as a feed additive on growth and physiological response of Oscar fish. The results of this study showed that fish fed on diets including $13.75-55 \mathrm{~g} / \mathrm{kg}$ SP had improved, HCT, MCH and MCHC compared with the control. In addition, these results are completely in agreement with Seyidoglu et al., (2019) who mentioned that SP could improve hematological and morphological parameters when they studied its effect on morphological and hematological factors resulting from social stress in male rats. Roberto, (2015) and Balasubramani et al., (2016) showed that SP contains minerals such as iron, magnesium, calcium, and phosphorus. SP is a splendid source of iron which contains 20 times more iron than wheat germ so spirulina is a good treatment for anemia . These results are supported by the results published by Visnegarwala and Mahesh, (2017) has shown the effects of $\mathrm{SP}$, blue green algae, as an alternative to iron supplements, to not only alleviate the anemia of pregnancy but also have impact on the fetal and maternal outcomes, through its impact on the gut microbiome. Also, Radha and Chandra, (2018) has shown that SP is useful for anemic persons because it is a good source of iron, meaning it is excellent for women during pregnancy. In addition, Pugazhendy et al., (2012) reported that spirulina could improve $\mathrm{Hb}, \mathrm{MCH}$ and $\mathrm{MCHC}$ in anemic children .The nutritional benefits of the spirulina over the vitamins and mineral supplementations might refer to the functional activities of it.

Table 9 shows the effect of SP algae as a casein replacement on CAT, MDA, GPx and SOD. In all groups of $\mathrm{SP}(1,2 \& 3)$ recorded significant increases in antioxidant enzymes (SOD, CAT\& GPx) in liver tissue compared with casein 2. On the other side, the results of MDA recorded significant increase in groups of casein compared with the groups of SP. In this study, oxidative stress was confirmed by decreased antioxidant enzyme (SOD, CAT\& GPx) as well as increased MDA level. Administration of SP 
increased antioxidant enzymes, which can be attributed to its antioxidant activities. These findings indicate that SP antioxidant activities due to having several antioxidant compounds such as various vitamins, phycocyanin, selenium and polyunsaturated fatty acids. Abd el-Baky et al., (2009) have demonstrated that SP is able to increase its antioxidant activity during oxidative stress elevation and has a self-regulating antioxidant activity against the intensity of oxidative stress. Consistently, many studies have reported similar findings. Ramez et al., (2021) have investigated the therapeutic effects of SP and (MGT) in S. mansoni-infected mice combined with tracing their possible antioxidant and antiinflammatory impacts and their protective potency. They reached to the antioxidant effects of SP and/or MGT against S. mansoni mediated oxidative stress in serum MDA was significantly elevated, and the CAT, SOD, and GSH-Px activities and TAC levels were significantly reduced in infected untreated mice compared with the control group. Recent studies have shown the ameliorative effect of SP against AA toxicity in rats. They found that rats treated with $500 \mathrm{mg} / \mathrm{kg}$ SP only did not show obvious changes in hepatic oxidative stress and antioxidant biomarkers compared to the normal untreated rats. Similarly, rats treated with $1000 \mathrm{mg} / \mathrm{kg} \mathrm{SP}$ only did not reveal obvious changes in hepatic oxidative stress and antioxidant biomarkers except GSH, SOD, and CAT, which showed significant increase compared to the normal untreated rats (Bin-Jumah et al., 2021). According to El-Beltagi et al., (2020) who have evaluated hepato protective and antioxidant activities of SP and pomegranate juice in rats against hepatotoxicity induced by carbon tetrachloride (CCl4). They have demonstrated that SP and pomegranate juice had hepatoprotective effect on $\mathrm{CCl} 4$ caused hepatotoxicity in rats through its antioxidant activity. As well as Xiang $\boldsymbol{e t}$ al.,(2018) have studied the protective effect and mechanism of selenium-enriched SP on chronic alcohol-induced liver injury. They noticed that SeSP or SP decreased the MDA level in the livers of alcoholtreated mice .The results have confirmed that pretreatment with Se-SP or SP could improve the activities of SOD and GSH-Px. Furthermore, SP induced a marked elevation in the antioxidant enzyme activities and GSH level in the renal and hepatic tissues (Wu et al., 2016). Although an analysis study 
revealed that the distributions of the total phenolic compounds varied between commercial products, it was claimed that chlorogenic acid, synaptic acid, salicylic acid, trans-cinnamic acid, and caffeic acid were commonly present in spirulina (Miranda et al., 1998). The antioxidant compounds in spirulina, such as phycobilins and phycocyanins, also inhibit the activities of catalytic enzymes, such as lipoxygenase and cyclooxygenase, or enhance the activity of enzymes, such as glutathione peroxidase, catalase, and superoxide dismutase (Bhat and Madyastha., 2001 \&Chaiklahan et al., 2013). These polyphenols were reported to have antiinflammatory, antiviral, antioxidant, antithrombotic, vasodilatory, antidiabetic, neuroprotective, hepato-protective, and anti-carcinogenic properties (Bhat and Madyastha, 2001).

Data in Table10 show the effect of SP algae as a casein replacement on $\alpha \mathrm{TNF}$ and G.H in serum. The mean value of growth hormone recorded a significant increase in SP groups compared with casein 2 . On the other side, the results of $\alpha$ TNF recorded a significant decrease in groups of SP compared with the groups of casein. In previous studies, treatment with SP after AA intoxication reduced TNF- $\alpha$, IL$1 \beta$ and IL- 6 serum levels. This is probably because SP has antioxidative and antiinflammatory properties (Pak et al., 2012 and Salzano et al., 2014). These results is accordance with Ramez et al., (2021) who have investigated the therapeutic effects of SP and MGT (Magnesium Lthreonate) in S.mansoni-infected mice combined with tracing their possible antioxidant and antiinflammatory impacts and their protective potency. They found that treatment with SP and/or MGT attenuated the changes in serum cytokines induced by $S$. mansoni infection; TNF- $\alpha$, IFN- $\gamma$, and IL-13 were reduced, and IL10 was significantly decreased in SP- and/or MGT-treated groups. As well as the results were agreed with Jin et al.,(2020) who have evaluated the effects of SP on the bone metabolism and antioxidant profiles of three-week-old growing male rats. They have observed enhancement of bone growth and bone strength by SP treatment, although the SP-fed groups showed continuous increases in GH level over the 7week study in a dose-dependent manner. They suggested that SP treatment can increased GH levels over time, potentially allowing bones to grow continuously. Our results accordance with Bin- 
Jumah et al., (2021) who evaluated the ameliorative effect of SP against AA toxicity in rats. They found that the levels of TNF- $\alpha$ were markedly reduced. The present results also came in accordance with another study, which mentioned that this protection could also be attributed to the abundant content of antioxidant active ingredients, such as C-phycocyanin, vitamins, $B$-carotene, and minerals in SP algae (Avdagicet al., 2008).

\section{CONCLUSION:}

Finally, based on all the results, Spirulina platensis can be considered very nutritious. SP has antioxidant and anti-inflammatory properties. In addition, the level of hemoglobin in the blood and the

\section{REFERENCES}

\section{Abdel-Daim MM (2014):}

Pharmacodynamic interaction of Spirulina platensis with erythromycin in Egyptian Baladi bucks (Capra hircus). Small Ruminant Research; 120:234-241.
Abdel-Daim M; El-Bialy BE; Rahman HG; Radi AM; Hefny HA and Hassan AM (2016):
Antagonistic effects of Spirulina platensis against sub-acute deltamethrin

number of red blood cells showed a significant increase, and the average value of the growth hormone recorded a significant increase in all groups treated with spirulina. Due to the higher content of protein and lower amount of carbohydrates and fats in spirulina powder. SP can be used as a good protein replacement. This makes it an ideal food especially in the growing stage. Therefore, this study recommends the introduction of spirulina in many food products, especially for children, avoiding protein consumption above the current RDA (high protein diet) for healthy children due to its potential disease risks.

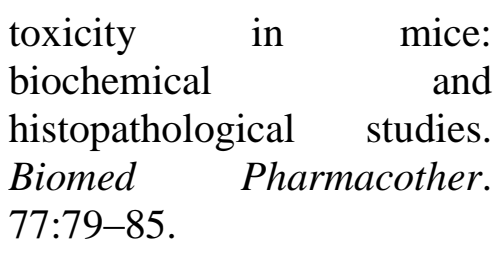

Abdelkhalek NK; Ghazy EW
and Abdel-Daim MM (2014): Pharmacodynamic interaction of Spirulina platensis and deltamethrin in freshwater fish Nile tilapia, Oreochromisniloticus: impact on lipid peroxidation and oxidative stress. Environ SciPollut Res Int. 22:3023-3031. 


\section{Abd El-Baky HH; El-Baz FK and El-Baroty GS (2009): \\ Enhancement of anti- oxidant production in Spirulina platensis under oxidative stress. Acta Physiol Plant. 31(3); 623- 631.}

\section{AOAC (2010):}

Official Methods of Analysis of Association of Official Chemists.18th Ed., Washington, D.C., USA.

Aparicio VA; Nebot E; Garcíadel Moral R; Machado-Vílchez M; Porres JM; Sánchez C and Aranda P (2013):

High-protein diets and renal status in rats. Nutr Hosp; 28(1):232-237.

\section{Aissaoui O; Amiali M; Bouzid} $\mathrm{N}$; Belkacemi $\mathrm{K}$ and Bitam $\mathrm{A}$ (2017):

Effect of Spirulina platensis ingestion on the abnormal biochemical and oxidative stress parameters in the pancreas and liver of alloxan-induced diabetic rats. Pharm Biol; 55(1): 1304-1312.

Avdagic N; Cosovic E; NakasIcindic E; Mornjakovic Z; Zaciragic $A$ and HadzovicDzuvo A (2008):
Spirulina platensis protects against renal injury in rats with gentamicin-induced acute tubular necrosis. Bosn J Basic Med Sci; 8:331-336.

Balasubramani R; Gupta SK; Cho W; Kim J; Lee S; Jeong K and Choi $H$ (2016) :

Microalgae potential and multiple roles - current progress and future prospects an over view. Sustainability, 8 (12).

Bhat VB and Madyastha KM (2001):

Scavenging of peroxy nitrite by phycocyanin and phycocyanobilin from Spirulina platensis: Protection against oxidative damage to DNA. Biochem. Biophys. Res. Commun, 285, 262-266.

Bergmeyer HU; Horder M and Rey J (1986):

Approved recommendation on IFCC methods for the measurement of catalytic enzymes. Part 2: IFCC method for aspartate aminotransferase. J. Clin. Chem. Clin. Biochem; 24:497-510.

Bhowmik D; Dubey J and Mehra S (2009): 
Probiotic efficiency of

Spirulina platensis -

Stimulating growth of lactic acid bacteria. World J Dairy Food Sci, 4(2):160-163.

Bin-Jumah MN; AL-Huqail AA; Abdelnaeim N; Kamel M; Fouda MA; Abulmeaty MM; Saadeldin IM and Abdel-Daim MM (2021):

Potential protective effects of Spirulina platensis on liver, kidney, and brain acrylamide toxicity in rats. Environmental Science and Pollution Research; 28: 26653-26663.

Chaiklahan R; Chirasuwan N; Triratana P; LohaV; Tia $S$ and Bunnag B (2013):

Polysaccharide extraction from Spirulina sp. and its antioxidant capacity. Int. J. Biol. Macromol, 58, 73-78.

\section{Chapman DG; Castillam R and} Campbell JA (1959):

Evaluation protein in food.

I.A. Method for the determination of protein efficiency ratio. Can. $J$. Biochem. Physiol, 37: 679686

\section{Cho JA; Baek SY; Cheong SH and Kim MR (2020):}

Spirulina Enhances Bone Modeling in Growing Male
Rats by Regulating GrowthRelated Hormones. Nutrients; 12: 1187

Dernikabsi S; Unal H; Karayucei I and Aral O (2010):

Effect of dietary supplementation of different rats of spirulina on growth and feed conversion in Guppy. Journal of animal and vertinery 9(9); 1395-1399.

\section{Díaz-Rúa R; Keijer J; Palou A;} Schothorst $E$ and Oliver $P$ (2017):

Long-term intake of a highprotein diet increases liver triacylglycerol deposition pathways and hepatic signs of injury in rats. $J$ Nutr Biochem ; 46:39-48.

\section{Drupt F (1974):}

"'Depression of human serum albumin. Farm. Boil., 9: 222- 229.

EL-Beltagi HS; Dhawi F; Ashoush IS and Ramadan MKh (2020):

Antioxidant, anti-cancer and ameliorative activities of Spirulina platensis and pomegranate juice against hepatic damage induced by CCl4. Notulae Botanicae 
Horti Agrobotanici ClujNapoca .48(4):1941-1956.

El-Moataaz $S$; Ismael $H$ and Abo-Rhyem S (2019):

Assessment of chemical composition of Spirulina platensis and its effect on fasting blood glucose and lipid profile in diabetic rats. JHIPH; 49(3):199-211.

Faulkner NR and King JW (1976):

Fundamental of Clinical Chemistry. 2-nd ed. Tietz Editor. Saunders Philadelphia. PP: 994-998.

Fechner A; Bohme CC; Gromer S; Funk M; Scirmer RH and Becker K (2001):

Antioxidant status and nitric oxide in the malnutrition syndrome Kwashiorkor, Pediatr. Res. 49 (n. 2) 237-243.

\section{Fossati P; Prencipe L and Berti} G (1980):

Use of 3,5-dichloro-2hydroxybenzenesulfonic acid/4-aminophenazone chromogenic system in direct enzymic assay of uric acid in serum and urine. Clinical Chemistry, 26(2), 227-231.
Gargouri M; Akrouti A; Magne C; El Feki A and Soussi A (2020):

Protective effects of spirulina against hematobiochemical alterations, nephrotoxicity, and DNA damage upon lead exposition. Human and Experimental Toxicology 39(6):; 855-869.

Gao H; Tanchico DT; Yallampalli U; Balakrishnan MP and Yallampalli C (2015):

Appetite regulation is independent of the changes in ghrelin levels in pregnant rats fed low-protein diet. Physiol Rep. 3(4): e12368.

Goldfarb S (1988):

Dietary factors in the pathogenesis and prophylaxis of calcium nephrolithiasis," Kidney International, vol. 34, no. 4, pp. 544-555.

Heidarpour A; Fourouzandeh A and Eghbalsaid $S$ (2011):

Effects of Spirulina platensis on performance, digestibility and serum biochemical parameters of Holstein calves. African Journal of Agricultural Research. 6 (22): 50615065. 
Iyer UM; Dhruv SA and Mani IU (2008):

Spirulina and its therapeutic implications as a food product. In: Gershwin M.E., Belay A. (eds): Spirulina in Human Nutrition and Health. Boca Raton, CRC Press: 51-70.

Jain NC (1986):

Schalm's Veterinary Hematology. Lea and Febiger, Philadelphia, PA.

Jin ACho; Seong Yeon Baek; Sun Hee Cheong and Mee Ree $\operatorname{Kim}(2020)$ :

Spirulina Enhances Bone Modeling in Growing Male Rats by Regulating GrowthRelated Hormones. Nutrients. (12): 2-19.

Khan M; Varadhara S; Gansesa LP; Shobha JC; Naidu MU and Parmandi NL (2005):

C-Phycocyanin protects against ischemia-reperfusion injury of heart through involvement of p38 and ERK signaling," Am. J. Physiol. Heart Circ. Physiol., vol. 290, no. 5, 2136-2145.

Khanna S; Gulati HK; Kumar S and Kapoor PK (2016):

Effect of Emblica officianalis and Spirulina platensis on growth performance and serum biochemical parameters in rabbits. Indian J. Anim. Res., 50 (6) : 915-918.

Kind AM and King SM (1954): Determination of Alkalin phosphatase activity in serum. J. of Clin. Pathol, 7(4): 322-326.

Marlina D (2019):

The Effectiveness of Spirulina Compared with Iron Supplement on Anemia among Pregnant Women in Indonesia. International Journal of Caring3 (13):1783-1787.

Minh NP (2014):

Effect of Saccharomyces cerevisiae, Spirulina and preservative supplementation to sweet bread quality in bakery. International Journal of Multidisciplinary Research and Development, 1: 36-44.

Miranda MS; Cintra RG; Barros SB and Mancini Filho J (1998):

Antioxidant activity of the microalga Spirulina maxima. Braz. J. Med. Biol. Res. 31, 1075-1079. 
Misra HP and Fridovich I (1972):

The role of superoxide anion in the autoxidation of epinephrine and a simple assay for superoxide dismutase. JBiol Chem. 25; 247(10):3170-5.

\section{Mohammadiazarm H; Maniat} M; Ghorbanijezeh Kh and hotbeddin N (2020):

Effects of spirulina powder (Spirulina platensis) as a dietary additive on Oscar fish, Astronotus ocellatus: Assessing growth performance, body composition, digestive enzyme activity, immune-biochemical

parameters, blood indices and total pigmentation. Aduaculture Nutrition. (27): 252-260.

Molina GE; Belarbi EH and Acién-Fernandez FG (2002):

Recovery of microalgal biomass and metabolites: process option and economics. Biotechnol; 20:491-515.

Moreira LM; Behling BS; Rodrigues RS; Costa JA and Soares la (2013):

Spirulina as a Protein Source in the Nutritional Recovery of Wistar Rats.
Braz. Arch. Biol. Technol56 (3):447-456.

MouketteMoukette B; Constant Anatole P; NyaBiapa CP; Njimou JR and Ngogang JY (2015):

Free radicals quenching potential, protective properties against oxidative mediated ion toxicity and HPLC phenolic profile of a Cameroonian spice: Piper guineensis. Toxicology report; 2:792-805.

Navacchi MFP; Carvalho JCM; Takeuchi KP and Danesi EDG (2012):

Development of cassava cake enriched with its own bran and Spirulina platensis. Acta Scientiarum Technology; 34: 465-472.

NCR (1995):

National Research Council, nutrient requirements of laboratory animals, fourth revised edition, pp.29-30.

\section{Nour El-Deen AES; Mansour} AEM and Taha A (2018):

High Protein Diet that Cause Weight Loss and Lower Blood Glucose Level Have a Serious Impact on the Kidney Functions of Male Diabetic Obese Albino 
Rats. Food and Nutrition Sciences, 9, 1174-1191.

Nuhu AA (2013):

Spirulina (Arthrospira): an important source of nutritional and medicinal Compounds: $\mathrm{p} 1-8$.

Pak W; Takayama F; Mine M; Nakamoto K; Kodo Y; Mankura M; Egashira T; Kawasaki $H$ and Mori A (2012):

Anti-oxidative and antiinflammatory effects of Spirulina on rat model of nonalcoholic steato hepatitis. $J$ Clin Biochem Nutr; 51:227234.

Pablos MI; Reiter RJ; Ortiz GG; Guerrero JM; Agapito MT; Chuang JI and Seweynek E ( 1998):

Rhythms of glutathione peroxidase and glutathione reductase in brain of chick and their inhibition by light. Neurochemistry

International, 32: 69-75.

Patton M; Plante I; Labrecque G; Beauchamp D; Patton CJ and Crouch SR (1977):

Enzymatic colorimetric method for determination of urea in serum. Anal. Che; 49: 464-469.

Pearson D (1981):
The Chemical Analysis of Food. 8 th ed. London: Churchill JA.

Pugazhendy K; Venkatesan S; Sangeetha D; Vasantharaja C; Prabakaran $S$ and Meenambal M (2012):

Fourier transform Infrared

(FT-IR) spectroscopic analysis of Spirulina. International Journal of Pharmaceutical and Biological Archives. 3(4): 969-972.

Radha P and Chandra V (2018): The rapeuticuses of spirulina. Journal of Current Innovation; 4(1): pp.975979.

Rajachar V; Gupta MK and Sengupta A (2016):

An intervention study for "Mission against malnutrition" in Bellary district, Karnataka. IPHA: Towards healthy lifestyle. Himalayan institute of medical sciences, Dehradun, Uttara hand.

Ramez AM; Elmahallawy EK; Elshopakey GE; Saleh AA; Moustafa SM; Al-Brakati A; Abdo W and El-Shewehy DM (2021):

Hepatosplenic Protective Actions of Spirulina platensis and Matcha Green Tea 
against Schistosoma mansoni Infection in Mice via Antioxidative and Antiinflammatory Mechanisms. frontiers invetrinary science. (8).p.p1-10.

Reboleira J; Freitas R; Pinteus S; Silva JAlves C; Pedrosa R and Bernardino $S$ (2019):

Chapter $39-$ Spirulina. Nonvitamin and Nonmineral Nutritional Supplements: 409-413.

\section{Roberto PS (2015):}

Photosynthetic bioenergy utilizing CO2: An approach on flue gases utilization for third generation biofuels. Journal of Cleaner Production, 98:53-65.

Salzano S; Checconi P; Hanschmann EM; Lillig CH; Bowler LD; Chan P; Vaudry D; Mengozzi $M$; Coppo $L$ and Sacre S (2014):

Linkage of inflammation and oxidative stress via release of glutathionylated peroxiredoxin-2, which acts as a danger signal. Proceedings of the National Academy of Sciences 111:12157-12162.

Seyidoglu N; Gurbanli R; Koseli E; Cengiz $F$ and Aydin C (2019):
The effects of Spirulina (Arthrospira) platensison morphological and hematological parameters evoked by social stress in male rats. Journal of Istanbul Veterinary Science; 3 (1): 21-27.

\section{Sgarbieri VC (1996):}

Proteínase malimentosprotéicos: propriedades, degradação, modificação. São Paulo,Ed. Varela;p. 517.

\section{Sharma V and Dunkwa V} (2012):

Development of Spirulina based "biscuits": a potential method of value addition. Studies on Ethno-Medicine; 6: 31-34.

\section{Sinha S; Patro N and Patro IK} (2019):

Amelioration

of

neurobehavioral and cognitive abilities of F1 progeny following dietary supplementation with Spirulina to protein malnourished mothers. Brain, Behavior, and Immunity.80:1-619.

\section{Sinha AK (1972):}

Colorimetric assay of catalase, Analytical Biochemistry; 47(2):389-394. 
Siva Kiran RR; Madhu GM and Satyanarayana SV (2015):

Spirulina in combating Protein Energy Malnutrition (PEM) and Protein Energy Wasting (PEW) - A review. J Nut Res; 3(1): 62-79.

Snedecor GW (1969):

Statistical methods "Fourth Ed.; The lowa state, college press, Ames lowa.

Sonnenwirth A and Jaret L (1980):

Graduate wholes Clinical Laboratory Methods and Diagnosis. Ed Mosby, London; Vol.18th: 258- 259.

Uchiyama $M$ and Mihara $M$ (1978):

Determination of malonaldehyde precursor in tissues by thiobarbituric acid test.AnalBiochem; 86: 271278.

Udayasree V; Manjula $K$ and Sowjanya M (2013):

Effect of Spirulina as a Nutritional Supplement in Malnourished Children. International journal of scientific research, Volume: 2 | Issue: 5 .311-312.
Visnegarwala FI and Mahesh RV (2017):

Spirulina: A panacea for iron-deficiency anemia of pregnancy (A hypothesisbased Review). J. Alt. Med. Res., 3(1): 123.

WHO - World Health

Organization:

[Cited 2011 Oct.19].

Avaiable from: http://www. who. int/en

Wu Q; Liu L; Miron A; Klimova B; Wan D and Kuca K (2016):

The antioxidant, immunemodulatory, and antiinflammatory activities of Spirulina: an overview. Arch Toxicol90:1817-1840.

Xiang Fu; ZhiwenZhong FengHu; Yi Zhang; Chunxia Li; YanPeng-LixueFeng; Jinglian Shenc and Bei Huang (2018):

The protective effects of selenium-enriched Spirulina platensis on chronic alcoholinduced liver injury in mice. The Royal Society of Chemistry. (9)3155-3165. 
Nutritional and Biological evaluation of using Spirulina algae as anew source of protein

Salha Salem Algohary, Zainab Abdul-Wahhab Salem and Amira M. El-Moslemany

Table1: Chemical composition of Spirulina platensis (g / 100g dry weight basis)

\begin{tabular}{|l|l|}
\hline Content in Spirulina platensis & Proximate composition (\%) \\
\hline Protein & $54.4 \pm 1.43$ \\
\hline Carbohydrates & $12.50 \pm 0.40$ \\
\hline Ash & $11.05 \pm 0.21$ \\
\hline Lipids & $10.23 \pm 0.26$ \\
\hline Moisture & $6.50 \pm 0.06$ \\
\hline Fibers & $5.25 \pm 0.25$ \\
\hline Total antioxidant activity & $39 \%$ \\
\hline amino acids (g/100g) & \\
\hline Tryptophan & 0.929 \\
\hline Threonine & 2.97 \\
\hline Isoleucine & 3.209 \\
\hline Leucine & 4.947 \\
\hline Lysine & 3.025 \\
\hline Methionine & 1.149 \\
\hline Cystine & 0.662 \\
\hline Phenylalanine & 2.777 \\
\hline Tyrosine & 2.584 \\
\hline Valine & 3.512 \\
\hline Arginine & 3.147 \\
\hline Histidine & 1.085 \\
\hline Alanine & 4.515 \\
\hline Aspartic acid & 4.793 \\
\hline Glutamic acid & 6.386 \\
\hline Glycine & 3.099 \\
\hline Proline & 2.382 \\
\hline Serine & 2.998 \\
\hline & \\
\hline
\end{tabular}

Values are means \pm standard deviation of three determinations $(n=3)$ 
Nutritional and Biological evaluation of using Spirulina algae as anew source of protein

Salha Salem Algohary, Zainab Abdul-Wahhab Salem and Amira M. El-Moslemany

Table 2: Effect of using Spirulina as a casein replacement on total feed intake, body weight gain, feed efficiency ratio, protein efficiency ratio and apparent digestibility Co-efficient of experimental rats

\begin{tabular}{|l|r|r|r|r|r|}
\hline $\begin{array}{l}\text { Parameters } \\
\text { / Groups }\end{array}$ & $\begin{array}{r}\text { FI } \\
\text { (g./period) }\end{array}$ & BWG \% & FER & PER & $\begin{array}{c}\text { A.D. } \\
\text { Coefficient }\end{array}$ \\
\hline Casein 1 & $324.33 \pm 7.55^{\mathrm{c}}$ & $50.35 \pm 9.71^{\mathrm{c}}$ & $0.18 \pm 0.01^{\mathrm{b}}$ & $0.22^{\varepsilon} \pm 0.02^{\mathrm{c}}$ & $0.93 \pm 0.004^{\mathrm{a}}$ \\
\hline Spirulina1 & $351.83 \pm 12.84^{\mathrm{a}}$ & $73.64 \pm 8.75^{\mathrm{a}}$ & $0.23 \pm 0.03^{\mathrm{a}}$ & $0.35 \pm 0.03^{\mathrm{c}}$ & $0.910 .001^{\mathrm{c}}$ \\
\hline Casein2* & $337.66 \pm 15.00^{\mathrm{bc}}$ & $48.94 \pm 10.61^{\mathrm{c}}$ & $0.15 \pm 0.03^{\mathrm{b}}$ & $0.193 \pm 0.04^{\mathrm{c}}$ & $0.93 \pm 0.001^{\mathrm{a}}$ \\
\hline Spirulina2 & $355.66 \pm 15.83^{\mathrm{ab}}$ & $67.32 \pm 13.47^{\mathrm{ab}}$ & $0.19 \pm 0.03^{\mathrm{b}}$ & $0.376 \pm 0.04^{\mathrm{a}}$ & $0.89 \pm 0.001^{\mathrm{d}}$ \\
\hline Casein3 & $330.66 \pm 14.30^{\mathrm{c}}$ & $54.40 \pm 15.76^{\mathrm{bc}}$ & $0.17 \pm 0.02^{\mathrm{b}}$ & $0.226 \pm 0.04^{\mathrm{b}}$ & $0.92 \pm 0.005^{\mathrm{b}}$ \\
\hline Spirulina3 & $343.81 \pm 18.4^{\mathrm{a}}$ & $59.00 \pm 10.50^{\mathrm{bc}}$ & $0.19 \pm 0.04^{\mathrm{b}}$ & $0.378 \pm 0.06^{\mathrm{a}}$ & $0.86 \pm .007^{\mathrm{a}}$ \\
\hline
\end{tabular}

Each value represents the mean $\pm S D$. Means in the same column with different superscript letters were significant at $p \leq 0.05 *$ Casein 2 as a negative control group

Table 3: Effect of using Spirulina as a casein replacement on aspartate aminotransferase, alanine aminotransferase and alkaline phosphates activities of experimental rats

\begin{tabular}{|l|l|l|l|}
\hline $\begin{array}{l}\text { Parameters } \\
\text { Groups }\end{array}$ & AST(IU/L) & ALT(IU/L) & ALP(IU/L) \\
\hline Casein1 & $55.60 \pm 3.57^{\mathrm{c}}$ & $30.00 \pm 2.8^{\mathrm{c}}$ & $183.50 \pm 2.42^{\mathrm{d}}$ \\
\hline Spirulina1 & $55.33 \pm 2.73^{\mathrm{c}}$ & $29.00 \pm 2.36^{\mathrm{c}}$ & $182.16 \pm 5.9^{\mathrm{d}}$ \\
\hline Casein2* & $62.83 \pm 5.77^{\mathrm{d}}$ & $22.50 \pm 1.87^{\mathrm{d}}$ & $188.16 \pm 4.35^{\mathrm{c}}$ \\
\hline Spirulina2 & $61.66 \pm 2.42^{\mathrm{d}}$ & $21.50 \pm 1.87^{\mathrm{d}}$ & $187.5 \pm 1.8^{\mathrm{c}}$ \\
\hline Casein3 & $123.00 \pm 4.09^{\mathrm{a}}$ & $63.50 \pm 1.87^{\mathrm{a}}$ & $220.83 \pm 10.59^{\mathrm{a}}$ \\
\hline Spirulina3 & $87.16 \pm 5.26^{\mathrm{b}}$ & $45.33 \pm 2.10^{\mathrm{b}}$ & $190.3 \pm 2.90^{\mathrm{b}}$ \\
\hline
\end{tabular}

Each value represents the mean $\pm S D$. Means in the same column with different superscript letters were significant at $p \leq 0.05 *$ Casein2 as a negative control group 
Nutritional and Biological evaluation of using Spirulina algae as anew source of protein

Salha Salem Algohary, Zainab Abdul-Wahhab Salem and Amira M. El-Moslemany

Table 4: Effect of using Spirulina as a casein replacement on serum total protein, albumin and globulin of experimental rats

\begin{tabular}{|l|l|l|l|}
\hline $\begin{array}{l}\text { Parameters } / \\
\text { Groups }\end{array}$ & $\begin{array}{l}\text { Total protein } \\
(\mathbf{g} / \mathbf{d l})\end{array}$ & $\begin{array}{l}\text { Albumin } \\
(\mathbf{g} / \mathbf{d l})\end{array}$ & $\begin{array}{l}\text { Globulin } \\
(\mathbf{g} / \mathbf{d l})\end{array}$ \\
\hline Casein1 & $6.10 \pm 0.05^{\mathrm{b}}$ & $3.23 \pm 0.01^{\mathrm{b}}$ & $2.85 \pm 0.044^{\mathrm{b}}$ \\
\hline Spirulina1 & $6.10 \pm 0.05^{\mathrm{b}}$ & $3.24 \pm 0.01^{\mathrm{b}}$ & $2.86 \pm 0.053^{\mathrm{b}}$ \\
\hline Casein2* & $6.14 \pm 0.01^{\mathrm{b}}$ & $3.25 \pm 0.01^{\mathrm{b}}$ & $2.89 \pm 0.035^{\mathrm{b}}$ \\
\hline Spirulina2 & $6.15 \pm 0.02^{\mathrm{b}}$ & $3.24 \pm 0.01^{\mathrm{b}}$ & $2.91 \pm 0.034^{\mathrm{b}}$ \\
\hline Casein3 & $6.18 \pm 0.0^{\mathrm{a}}$ & $3.31 \pm 0.01^{\mathrm{a}}$ & $2.87 \pm 0.033^{\mathrm{b}}$ \\
\hline Spirulina3 & $6.15 \pm 0.14^{\mathrm{b}}$ & $3.27 \pm 0.012^{\mathrm{b}}$ & $2.88 \pm 0.024^{\mathrm{b}}$ \\
\hline
\end{tabular}

Each value represents the mean $\pm S D$. Means in the same column with different superscript letters were significant at $p \leq 0.05 *$ Casein 2 as a negative control group

Table 5: Effect of using Spirulina as a casein replacement on urea, uric acid, Creatinine and creatinine Clearance of experimental rats

\begin{tabular}{|l|l|l|l|l|}
\hline $\begin{array}{l}\text { Parameters } \\
\text { Groups }\end{array}$ & Urea(mg/d) & $\begin{array}{l}\text { Uric } \\
\text { acid(mg/dl) }\end{array}$ & $\begin{array}{l}\text { Creatinine } \\
(\mathbf{m g} / \mathbf{d l})\end{array}$ & $\begin{array}{l}\text { Creatinine } \\
\text { Clearance }\end{array}$ \\
\hline Casein1 & $29.65 \pm 1.9^{\mathrm{c}}$ & $2.6 \pm .0 .25^{\mathrm{c}}$ & $0.74 \pm 0.03^{\mathrm{c}}$ & $1.41 \pm 0.39^{\mathrm{b}}$ \\
\hline Spirulina1 & $28.56 \pm 1.8^{\mathrm{c}}$ & $2.55 \pm 0.15^{\mathrm{c}}$ & $0.74 \pm 0.02^{\mathrm{c}}$ & $1.37 \pm 0.02^{\mathrm{b}}$ \\
\hline Casein2* & $28.16 \pm 1.4^{\mathrm{cd}}$ & $2.28 \pm 0.06^{\mathrm{d}}$ & $0.70 \pm 0.04^{\mathrm{d}}$ & $1.44 \pm 0.63^{\mathrm{b}}$ \\
\hline Spirulina2 & $27.80 \pm 1.2^{\mathrm{cd}}$ & $2.24 \pm 0.02^{\mathrm{d}}$ & $0.71 \pm 0.01^{\mathrm{cd}}$ & $1.43 \pm 0.02^{\mathrm{b}}$ \\
\hline Casein3 & $37.64 \pm 1.8 \mathrm{a}$ & $3.61 \pm 0.30^{\mathrm{a}}$ & $0.93 \pm 0.02^{\mathrm{a}}$ & $1.72 \pm 0.02^{\mathrm{a}}$ \\
\hline Spirulina3 & $34.22 \pm 0.8^{\mathrm{b}}$ & $3.24 \pm 0.02^{\mathrm{b}}$ & $0.83 \pm 0.01^{\mathrm{b}}$ & $1.69 \pm 0.02^{\mathrm{a}}$ \\
\hline
\end{tabular}

Each value represents the mean $\pm S D$. Means in the same column with different superscript letters were significant at $p \leq 0.05 *$ Casein2 as a negative control group 
Nutritional and Biological evaluation of using Spirulina algae as anew source of protein

Salha Salem Algohary, Zainab Abdul-Wahhab Salem and Amira M. El-Moslemany

Table 6: Effect of using Spirulina as a casein replacement on hemoglobin, RBCs and WBCs of whole blood of rats

\begin{tabular}{|c|c|c|c|}
\hline $\begin{array}{l}\text { Parameters / } \\
\text { Groups }\end{array}$ & $\begin{array}{l}\text { Hemoglobin } \\
\text { (g/dl) }\end{array}$ & $\operatorname{RBCs} 10^{6} \mu / L$ & $\begin{array}{l}\text { WBCsThous } \\
\text { and } / \mu \mathrm{m}\end{array}$ \\
\hline Casein1 & $11.33 \pm 0.2^{\mathrm{f}}$ & $2.49 \pm 0.16^{\mathrm{c}}$ & $13.10 \pm 0.37^{b}$ \\
\hline Spirulina1 & $13.06 \pm 0.51^{\mathrm{d}}$ & $4.4 \pm 0.24^{\mathrm{c}}$ & $14.22 \pm 1.52^{\mathrm{b}}$ \\
\hline Casein2* & $12.22 \pm 0.52^{\mathrm{e}}$ & $3.12 \pm 0.34^{\mathrm{d}}$ & $12.98 \pm 0.14^{\mathrm{cb}}$ \\
\hline Spirulina2 & $14.46 \pm 0.55^{\mathrm{b}}$ & $4.9 \pm 0.47^{b}$ & $13.8 \pm 1.20^{\mathrm{b}}$ \\
\hline Casein3 & $13.82 \pm 0.73^{\mathrm{c}}$ & $4.7 \pm 0.43^{b c}$ & $17.76 \pm 0.75^{\mathrm{a}}$ \\
\hline Spirulina3 & $15.26 \pm 0.52^{\mathrm{a}}$ & $5.7 \pm 0.26^{\mathrm{a}}$ & $12.27 \pm 1.10^{\mathrm{c}}$ \\
\hline
\end{tabular}

Each value represents the mean \pm SD. Means in the same column with different superscript letters were significant at $p \leq 0.05 *$ Casein2 as a negative control group

Table 7: Effect of using Spirulina as a casein replacement on P.Count, hematocrit, Lymphocytes and Monocytes of whole blood of rats

\begin{tabular}{|l|l|l|l|l|}
\hline $\begin{array}{l}\text { Parameters / } \\
\text { Groups }\end{array}$ & $\begin{array}{l}\text { Hematocrit } \\
(\%)\end{array}$ & L.Cyte\% & M.Cyte\% & P.Count(k/ul) \\
\hline Casein1 & $33.99 \pm 0.31^{\mathrm{d}}$ & $89.0 .86 \pm 0.86^{\mathrm{d}}$ & $2.4 \pm 0.12^{\mathrm{d}}$ & $823.66 \pm 11.8^{\mathrm{c}}$ \\
\hline Spirulina1 & $39.18 \pm 0.46^{\mathrm{a}}$ & $90.19 \pm 0.56^{\mathrm{a}}$ & $3.9 \pm 0.49^{\mathrm{a}}$ & $725.16 \pm 26.9^{\mathrm{d}}$ \\
\hline Casein2* & $36.66 \pm 0.36^{\mathrm{c}}$ & $90.67 \pm 11.5$ & $2.9 \pm 0.14^{\mathrm{bc}}$ & $849.33 \pm 6.1^{\mathrm{c}}$ \\
\hline Spirulina2 & $43.38 \pm 0.58^{\mathrm{ab}}$ & $96.83 \pm 1.3^{\mathrm{b}}$ & $2.94 \pm 0.29^{\mathrm{b}}$ & $822.16 \pm 60.95^{\mathrm{c}}$ \\
\hline Casein3 & $41.46 \pm 0.57^{\mathrm{bc}}$ & $82.37 \pm 0.22^{\mathrm{d}}$ & $2.5 \pm 0.26^{\mathrm{cd}}$ & $1182.21 \pm 46.5^{\mathrm{a}}$ \\
\hline Spirulina3 & $45.78 \pm 0.25^{\mathrm{ab}}$ & $99.01 \pm 1.06^{\mathrm{c}}$ & $2.64 \pm 0.23^{\mathrm{cd}}$ & $924.66 \pm 53.7^{\mathrm{b}}$ \\
\hline
\end{tabular}

Each value represents the mean $\pm S D$. Means in the same column with different superscript letters were significant at $p \leq 0.05 *$ Casein 2 as a negative control group 
Nutritional and Biological evaluation of using Spirulina algae as anew source of protein

Salha Salem Algohary, Zainab Abdul-Wahhab Salem and Amira M. El-Moslemany

Table 8: Effect of using Spirulina as a casein replacement on MCV, MCH and MCHC of whole blood of rats

\begin{tabular}{|l|l|l|l|}
\hline $\begin{array}{l}\text { Groups/ } \\
\text { parameter }\end{array}$ & $\begin{array}{l}\text { MCH } \\
(\mathbf{p g})\end{array}$ & $\begin{array}{l}\text { MCV } \\
(\mathbf{f L})\left(\mathbf{u m}^{3}\right)\end{array}$ & $\begin{array}{l}\text { MCHC } \\
(\mathbf{g} / \mathbf{d l})\end{array}$ \\
\hline Casein1 & $66.01 \pm 2.21^{\mathrm{e}}$ & $26.94 \pm 0.23^{\mathrm{e}}$ & $24.94 \pm 3.50^{\mathrm{d}}$ \\
\hline Spirulina1 & $76.60 \pm 4.46^{\mathrm{d}}$ & $27.82 \pm 0.51^{\mathrm{d}}$ & $34.19 \pm 1.2^{\mathrm{c}}$ \\
\hline Casein2* & $73.09 \pm 3.91^{\mathrm{d}}$ & $30.38 \pm 0.78^{\mathrm{c}}$ & $25.63 \pm 0.30^{\mathrm{d}}$ \\
\hline Spirulina2 & $85.5 \pm 3.49^{\mathrm{c}}$ & $31.41 \pm 0.91^{\mathrm{b}}$ & $36.72 \pm 2.5^{\mathrm{b}}$ \\
\hline Casein3 & $126.6 \pm 0.51^{\mathrm{b}}$ & $32.08 \pm 0.65^{\mathrm{a}}$ & $38.37 \pm 1.07^{\mathrm{ab}}$ \\
\hline Spirulina3 & $175.11 \pm 27.3^{\mathrm{a}}$ & $33.41 \pm 0.33^{\mathrm{a}}$ & $40.55 \pm 1.55^{\mathrm{a}}$ \\
\hline
\end{tabular}

Each value represents the mean $\pm S D$. Means in the same column with different superscript letters were significant at $p \leq 0.05 *$ Casein 2 as a negative control group

Table 9: Effect of using spirulina as a casein replacement on antioxidant enzymes and Manoldehyde in liver tissue homogenate of experimental rats

\begin{tabular}{|l|l|l|l|l|}
\hline $\begin{array}{l}\text { Parameters } \\
\text { Groups }\end{array}$ & MDA $(\mathbf{m m o l} / \mathbf{g})$ & SOD$(\mathbf{u} / \mathbf{m g})$ & CAT(u/mg) & GPx $(\mathbf{n g} / \mathbf{m g})$ \\
\hline Casein1 & $0.296 \pm .0049^{\mathrm{a}}$ & $0.116 \pm .003^{\mathrm{e}}$ & $0.089 \pm .0135^{\mathrm{f}}$ & $0.125 \pm .003^{\mathrm{f}}$ \\
\hline Spirulina1 & $0.277 \pm .0040^{\mathrm{b}}$ & $0.179 \pm .002^{\mathrm{d}}$ & $0.175 \pm .0041^{\mathrm{e}}$ & $0.189 \pm .002^{\mathrm{e}}$ \\
\hline Casein2* & $0.234 \pm .0030^{\mathrm{d}}$ & $0.175 \pm .003^{\mathrm{d}}$ & $0.201 \pm .0031^{\mathrm{d}}$ & $0.199 \pm .003^{\mathrm{d}}$ \\
\hline Spirulina2 & $0.200 \pm .0041^{\mathrm{e}}$ & $0.229 \pm .003^{\mathrm{b}}$ & $0.230 \pm .0032^{\mathrm{b}}$ & $0.241 \pm .004^{\mathrm{c}}$ \\
\hline Casein3 & $0.242 \pm .0071^{\mathrm{c}}$ & $0.195 \pm .004^{\mathrm{c}}$ & $0.210 \pm .0023^{\mathrm{c}}$ & $0.248 \pm .005^{\mathrm{b}}$ \\
\hline Spirulina3 & $0.129 \pm .0032^{\mathrm{f}}$ & $0.272 \pm .002^{\mathrm{a}}$ & $0.269 \pm .0051^{\mathrm{a}}$ & $0.289 \pm .005^{\mathrm{a}}$ \\
\hline
\end{tabular}


Nutritional and Biological evaluation of using Spirulina algae as anew source of protein

Salha Salem Algohary, Zainab Abdul-Wahhab Salem and Amira M. El-Moslemany

Each value represents the mean $\pm S D$. Means in the same column with different superscript letters were significant at $p \leq 0.05$. * Casein2 as a negative control group

Table 10: Effect of using Spirulina as a casein replacement on tumor necrosis factor, and growth hormone in serum of experimental rats

\begin{tabular}{|c|c|c|}
\hline $\begin{array}{l}\text { Parameters / } \\
\text { Groups }\end{array}$ & G.H (pg/mg) & TNF (pg/ml) \\
\hline Casein1 & $0.157 \pm .002^{f}$ & $0.237 \pm 0.0023^{a}$ \\
\hline Spirulina1 & $0.234 \pm .002^{\mathrm{e}}$ & $0.218 \pm 0.0070^{b}$ \\
\hline Casein2* & $0.366 \pm .005^{\mathrm{d}}$ & $0.198 \pm 0.0023^{c}$ \\
\hline Spirulina2 & $0.393 \pm .008^{c}$ & $0.179 \pm 0.0036^{\mathrm{d}}$ \\
\hline Casein3 & $0.599 \pm .004^{\mathrm{b}}$ & $0.241 \pm 0.0228^{a}$ \\
\hline Spirulina3 & $0.716 \pm .006^{\mathrm{a}}$ & $0.190 \pm 0.0051^{\mathrm{c}}$ \\
\hline
\end{tabular}

Each value represents the mean $\pm S D$. Means in the same column with different superscript letters were significant at $p \leq 0.05$. * Casein 2 as a negative control group 


\section{التقيم الغذائي والبيولوجي على استخدام طملب الاسبيرولينا كمصدر جديد للبروتين

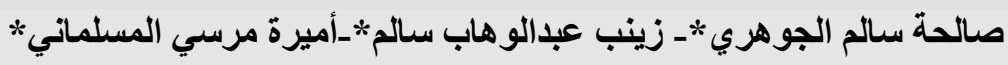 \\ *قسم التغذية وعلوم الأطعمة كلية الاقتصاد المنزلي-جامعة الأزهر}

تستخدم طحالب الاسبيرولينا كمادة غذائية شائعة في جميع أنحاء العالم منذ القدم بتهذف هذه

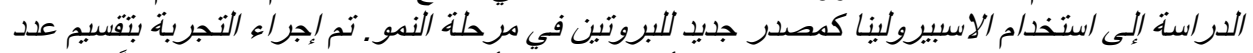

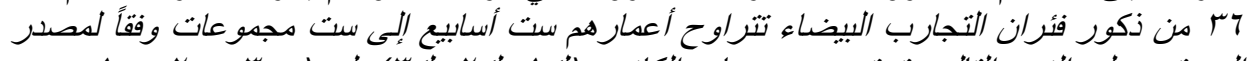

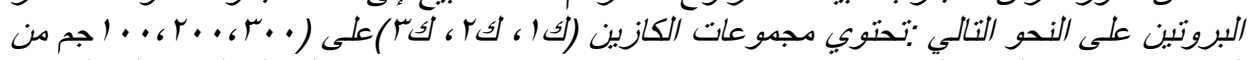

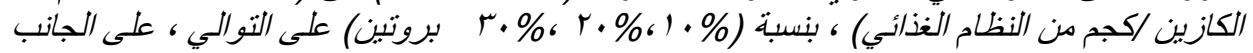

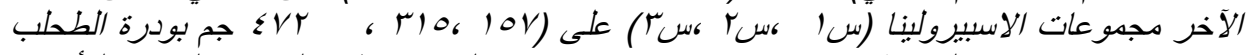

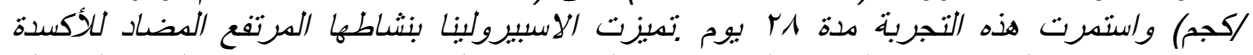
(\% \% ( r, r)

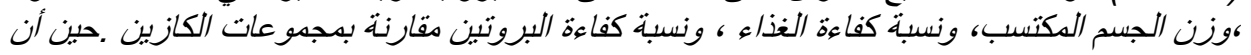

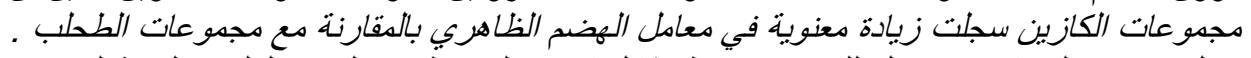

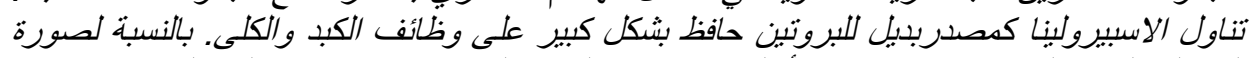

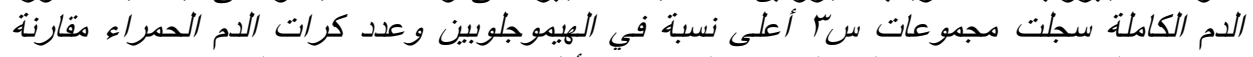

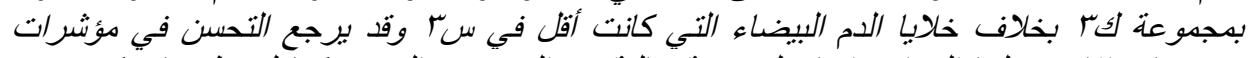

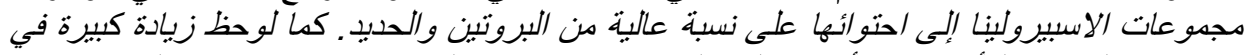

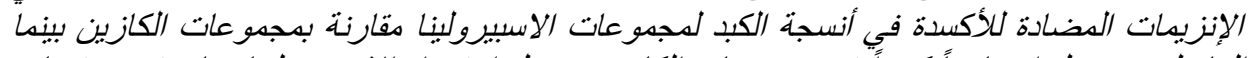

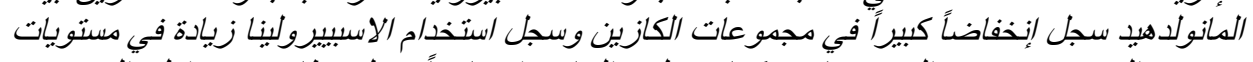

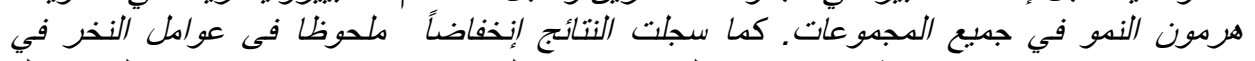
مجدوعات الاسبيرولينا مقارنة بمجمو عات الكازين. وفي الختام: يمكن استخدام الاسبيرولينا كبديل جديد للبرونين.

الكلمات المفتاحية: طحلب الاسبيرولينا ـالمؤشرات الدموية- معامل الهضم الظاهري- الإنزبيات المضادة للأكسدة المفتاحية 